\title{
Current Leakage Problem
}

National Cancer Institute

\section{Source}

National Cancer Institute. Current Leakage Problem. NCI Thesaurus. Code C92044.

Problems related to leakage currents which may cause electric shock. These currents usually flow through the protective ground conductor. In its absence, these currents could flow from the device to the ground via the human body. 